\title{
PENINGKATAN PRODUKSI PADI MELALUI PENERAPAN SRI (SYSTEM OF RICE INTENSIFICATION) DI KABUPATEN SOLOK SELATAN
}

\author{
Joko Adrianto' ${ }^{1}$, Harianto ${ }^{2}$, dan M. Parulian Hutagaol ${ }^{3}$ \\ 1)Program Studi Ilmu Ekonomi Pertanian, Sekolah Pascasarjana, Institut Pertanian Bogor \\ 2)Departemen Agribisnis, Fakultas Ekonomi dan Manajemen, Institut Pertanian Bogor \\ 3)Departemen Ilmu Ekonomi, Fakultas Ekonomi dan Manajemen, Institut Pertanian Bogor \\ e-mail : 1)adriantosikumbang@gmail.com
}

\begin{abstract}
This study was aimed (1) to analyze factors affecting adoption of System of Rice Intensification (SRI), (2) to measure technical, allocative and economic efficiencies of rice farming (3) to identify the factors that influence the technical inefficiency of rice farming. The data was gather from 90 rice farmers in the study area. The analysis method used are probit fuction model and the stochastic frontier production and frontier cost function. The result showed that variables implementation of SRI was affected by factors such as land, frequency extension, and long periode of farm group membership. The implementation of SRI were able to improve the productivity of rice farming. The level of technical efficiency (TE) was efficient with average TE value either SRI and without SRI rice farming each of 0.88 and 0.89 . The level of allocative and economic efficiencies of SRI and without SRI rice farming was inefficient. The average values of allocative efficiency of SRI and without SRI rice farming were each 0.41 and 0.42 . The average values of economic efficiency of SRI and without SRI rice farming were each 0.36 and 0.37 . Family size was significantly to reduce of level technical inefficiency of SRI and family size, land tenure, farm status was significantly to reduce of level technical inefficiency of without SRI rice farming. Policy implications, the goverment needs to support accessibility and availability of production inputs to enhancement the productivity of rice farming.
\end{abstract}

Keywords: rice, SRI, efficiency, stochastic frontier

\section{PENDAHULUAN}

\section{LATAR BELAKANG}

Sektor pertanian merupakan salah satu leading sector dalam perekonomian Indonesia. Hal ini ditunjukkan dengan cukup tingginya kontribusi sektor pertanian terhadap pendapatan domestik bruto (PDB) Indonesia yang mencapai 14,43 persen, satu tingkat dibawah sektor industri pengolahan yakni sebesar 23,69 persen pada tahun 2013. Selain dalam pembentukan PDB, sektor pertanian juga berperan dalam penerimaan devisa, penyerapan tenaga kerja, penyedia bahan baku industri dan penyedia pangan (BPS, 2014a).

Seiring dengan bertambahnya jumlah penduduk Indonesia dengan laju pertumbuhan sebesar 1,49 persen per tahun dan diiringi dengan besarnya konsumsi beras per kapita sebesar 135,01 kg/kapita/tahun maka kebutuhan bahan pangan beras di Indonesia dimasa akan datang semakin meningkat (Direktorat Pangan dan Pertanian, 2013). Untuk mengimbangi peningkatan kebutuhan beras tersebut, maka harus diimbangi dengan peningkatan produksi beras secara nasional. Dari tahun 2012 ke tahun 2013 produksi padi nasional mengalami peningkatan produksi sebesar 3,22 persen, namun dari tahun 2013 ke tahun 2014 produksi padi diperkirakan menurun menjadi 1,98 persen (BPS, 2014b).

Menurut Irawan (2005), melambatnya laju pertumbuhan produksi padi nasional disebabkan oleh adanya kompetisi dalam penggunaan lahan, perubahan iklim yang ekstrim, degradasi sumberdaya pertanian, terbatasnya dukungan infrastruktur pertanian serta tidak adanya terobosan teknologi padi secara signifikan. Arifin (2004) juga mengemukakan bahwa setelah terjadinya swasembada beras pada tahun 1984, 
perkembangan produksi padi menjadi lambat dan lebih banyak ditentukan oleh luas panen, karena relatif sedikitnya terobosan teknologi baru dibidang produksi. Upaya peningkatan produksi padi dapat dilakukan salah satunya melalui upaya intensifikasi tanaman padi atau system of rice intensification (SRI). SRI merupakan teknologi budidaya alternatif yang berpeluang besar untuk dapat meningkatkan produktivitas padi sawah di Indonesia dengan cara mengubah pengelolaan tanaman, tanah, air dan unsur hara. Penerapan SRI pada usahatani padi telah banyak dilakukan di Indonesia. Uji coba teknik SRI pertama kali dilaksanakan oleh Lembaga Penelitian dan Pengembangan Pertanian di Sukamandi Jawa Barat menghasilkan padi rata-rata 8,2 ton/ha (Uphoff 2002). Hasil penelitian Pusat Penelitian Pertanian di Puyung NTB, metode SRI memberikan hasil rata-rata 9 ton/ha (Sato 2007), di Kabupaten Lima Puluh Kota usahatani padi berbasis SRI mencapai 8 ton/ha (Djinis et al., 2008), di Kota Padang 10,8 ton/ha (Anwar et al., 2009), di Kabupaten Sleman 9,6 ton/ha (Darmadji 2011), dan dikawasan Indonesia timur mencapai 7,4 ton/ha (Sato 2007). Hasil temuan diatas juga diperkuat oleh penelitian Pirngadi (2009) yang menemukan bahwa usahatani padi dengan penerapan SRI dapat meningkatkan produksi padi sekitar 8 ton/ha.

Kabupaten Solok Selatan merupakan salah satu kabupaten di Provinsi Sumatera Barat yang turut berkontribusi dalam mengusahakan budidaya padi berbasis SRI. Penerapan SRI di Kabupaten Solok Selatan didasari bahwa daerah ini merupakan lumbung pangan di Provinsi Sumatera Barat. Usahatani padi merupakan sumber pendapatan utama sebagian besar petani di Kabupaten Solok Selatan. Menurut data BPS (2014c), Kabupaten Solok Selatan memiliki areal luas panen sebesar $28.788 \mathrm{Ha}$, jumlah produksi gabah 121.939 ton dan produktivitas sebesar 4,23 ton/ha. Produktivitas ini masih tergolong rendah apabila dibandingkan dengan hasil penelitian-penelitian yang telah dilakukan. Pemerintah Kabupaten Solok Selatan mendukung penuh upaya pengem- bangan usahatani padi berbasis SRI sebagai program peningkatan produksi padi melalui penerapan teknologi.

Menurut Wardana et al. (2005), teknologi SRI bisa menjadi pilihan teknologi yang menarik dalam usahatani padi karena ada efisiensi penggunaan input benih dan penghematan air serta mendorong penggunaan pupuk organik. Dengan demikian bisa menjaga kesuburan tanah dan mengurangi ketergantungan pada pupuk anorganik. Dalam penerapan SRI ada beberapa komponen penting yaitu: (1) bibit dipindah lapangan lebih awal, yakni pada saat bibit berumur 8-15 hari, (2) bibit ditanam satu bibit per lobang tanam, (3) jarak tanam yang lebar, yakni mencapai $25 \mathrm{~cm} \times 25 \mathrm{~cm}$ bahkan lebih, (4) kondisi tanah tetap lembab tapi tidak berair, dan (5) menggunakan bahan organik sehingga akan memperbaiki struktur tanah.

Penerapan usahatani padi berbasis SRI di Kabupaten Solok Selatan dilaksanakan melalui berbagai program diantaranya diberikan melalui sekolah lapang dan demontrasi teknologi pertanian (Demplot) sehingga teknologi SRI sangat efektif untuk diserap atau diadopsi oleh petani. Program sekolah lapang rutin dilakukan yang dimulai dari tahun 2009 sampai 2014. Setiap tahun program SRI diterapkan pada luasan 20 ha per kelompok tani yang tersebar di seluruh kecamatan yang merupakan sentra produksi padi. Namun penerapan program SRI oleh petani di Kabupaten Solok Selatan masih sangat rendah dan terbatas sampai tahun 2014. Program SRI masih diperlukan penyesuaian-penyesuaian yang secara tidak langsung merupakan proses pembelajaran petani dalam mengadopsi SRI sehingga pemerintah harus berupaya untuk melakukan evaluasi dalam penerapan SRI pada petani di Kabupaten Solok Selatan. Berangkat dari permasalahan diatas maka perlu dilakukan kajian mengenai faktor-faktor pendorong petani mengadopsi adopsi SRI di Kabupaten Solok Selatan, sehingga dapat dijadikan sebagai salah satu upaya dalam menyusun kebijakan bagi pemerintah untuk menarik 
perhatian petani agar beralih ke program padi berbasis SRI.

Penerapan padi berbasis SRI sangat ideal dilakukan pada kondisi lingkungan yang sangat mendukung terhadap komponenkomponen input inovasi yang dipersyaratkan dalam metode SRI seperti penggunaan bibit dari varietas unggul, bermutu dan bersetifikat, pemupukan yang sesuai dengan rekomendasi, dan manajemen budidaya yang baik dari persiapan lahan sampai pasca panen sehingga pada akhirnya akan memberikan output yang maksimal. Namun perlu dilakukan kajian mengenai penerapan SRI pada usahatani padi, apakah dengan menerapkan program SRI pada usahatani padi akan meningkatkan produktivitas dan efisiensi sehingga akan mendorong petani untuk menerapkan program ini pada usahatani padi. Selain itu kajian tersebut sangat penting dilakukan mengingat dengan kebijakan pemerintah untuk peningkatan produksi padi sehingga program swasembada beras nasional pada tahun 2015 dapat tercapai dengan adanya teknologi SRI ini.

Efisiensi usahatani padi dipengaruhi oleh kemampuan manajerial petani dalam memutuskan besaran input atau faktor-faktor produksi dalam penerapan komponen SRI. Selain itu, efisiensi usahatani padi juga dipengaruhi oleh faktor sosial ekonomi petani dan faktor yang berada diluar kendali petani seperti iklim/cuaca, ketersediaan air, kelembagaan usahatani dan lainnya. Interaksi faktor-faktor ini akan menentukan tingkat produktivitas dan efisiensi usahatani yang akan dicapai. Pertanyaannya adalah apakah petani padi di Kabupaten Solok Selatan mampu mengalokasikan input produksi secara efisien yang sesuai dengan rekomendasi dari komponen-komponen SRI yang disyaratkan. Maka dari itu perlu dilakukan kajian mengenai faktor-faktor yang mempengaruhi efisiensi usahatani padi berbasis SRI di Kabupaten Solok Selatan.

\section{TUJUAN PENELITIAN}

Tujuan penelitian ini adalah (1) menganalisis faktor-faktor sosial ekonomi yang mempengaruhi penerapan SRI oleh petani padi di Kabupaten Solok Selatan, (2) menganalisis tingkat efisiensi teknis, alokatif dan ekonomi usahatani padi, dan (3) mengidentifikasi faktor sosial ekonomi yang berpengaruh terhadap inefisiensi teknis usahatani padi di Kabupaten Solok Selatan.

\section{METODOLOGI PENELITIAN}

\section{KERANGKA PEMIKIRAN TEORITIS}

Penelitian ini mengacu pada konsep efisiensi yang dikemukakan oleh Farrel (1957) dan Coelli et al. (1998). Efisiensi digolongkan menjadi tiga yaitu efisiensi teknis (Technical Efficiency-TE), efisiensi alokatif (Allocative Efficiency-AE), dan efisiensi ekonomi (Economic Efficiency-EE).

Gambar 1 menjelaskan konsep pengukuran efisiensi. Titik P merupakan usahatani yang diuji efisiensinya. Kurva SS' merupakan isoquant frontier yang menggambarkan kombinasi input minimum untuk menghasilkan output satu unit yang secara teknis paling efisien. Titik $P$ dan $Q$ menggambarkan dua kondisi produsen dalam berproduksi dengan mengkombinasikan input dengan proporsi input $\mathrm{x}_{1} / \mathrm{y}$ dan $\mathrm{x}_{2} / \mathrm{y}$ yang sama. Produsen yang mengkombinasikan input untuk memproduksi satu unit output yaitu di titik P dikatakan tidak efisien secara teknis karena inefisiensi teknis digambarkan oleh jarak QP yaitu jumlah input yang dapat dikurangi secara proporsional tanpa mengurangi output. Kombinasi input secara teknis efisien yaitu titik $Q$ karena berada tepat di isoquan frontier. Besarnya nilai efisiensi teknis diukur dengan rasio OQ/OP.

Efisiensi alokatif menggunakan kriteria biaya minimum untuk menghasilkan sejumlah output tertentu pada isoquant. Informasi ratio harga input yaitu sebagai 
kemiringan garis isocost. Jika rasio hargaharga input $X_{1}$ dan $X_{2}$ ditunjukkan oleh garis $\mathrm{AA}^{\prime}$ maka efisiensi alokatif dapat dihitung. Efisiensi alokatif dapat ditentukan jika garis $\mathrm{AA}^{\prime}$ menyinggung kurva isoquant $\mathrm{SS}^{\prime}$ yaitu pada titik $Q^{\prime}$ yang diukur dengan ratio OR/OQ. Jarak RQ menunjukkan pengurangan biaya yang dapat dilakukan guna mencapai efisiensi alokatif. Titik yang efisien secara alokatif dan teknis atau dengan kata lain efisiensi secara ekonomi berada pada titik Q'. Efisiensi ekonomi merupakan perkalian antara efisiensi teknis dengan efisiensi alokatif. Untuk efisiensi ekonomi dihitung berdasarkan ratio OR/OP.

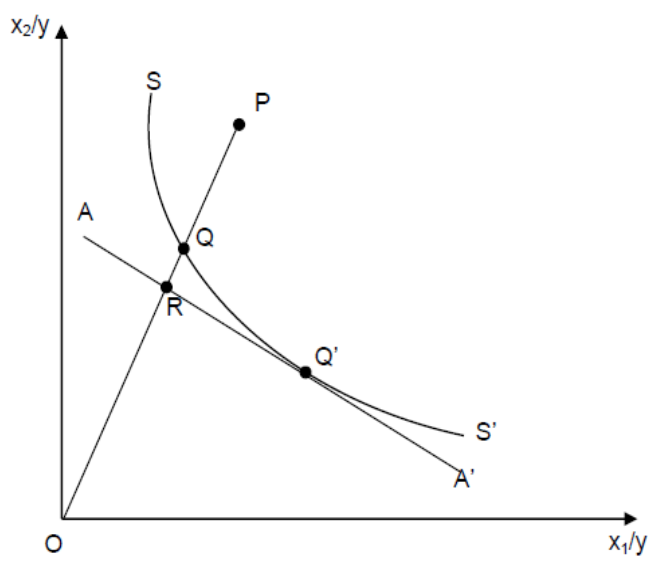

Gambar 1. Pengukuran Efisiensi

Sumber : Farrel (1957)

Dari uraian di atas menunjukkan bahwa efisiensi produksi merupakan ukuran relatif kemampuan suatu perusahaan di dalam menggunakan input untuk menghasilkan output tertentu pada tingkat teknologi tertentu. Coelli et al. (1998) menyatakan bahwa fungsi produksi frontier adalah fungsi produksi yang menggambarkan output maksimum yang dapat dicapai dari setiap tingkat penggunaan input. Apabila suatu usahatani berada pada titik di fungsi produksi frontier artinya usahatani tersebut efisiensi secara teknis. Jika fungsi produksi frontier diketahui maka dapat diestimasi inefisiensi teknis melalui perbandingan posisi aktual relatif terhadap frontier-nya.

Aigner et al. (1977) serta Meeusen dan Van Den Broeck (1997) dalam Coelli et al. (1998) mengemukakan fungsi stochastic frontier merupakan perluasan dari model asli deterministik untuk mengukur efek-efek yang tidak terduga (stochastic frontier) di dalam frontier produksi. Dalam fungsi produksi ini ditambahkan random error, $\mathrm{v}_{i}$ ke dalam variabel acak nonnegatif (non-negatif random), $\mathrm{u}_{\mathrm{i}}$ seperti dinyatakan dalam persamaan berikut ini :

$Y_{i}=X_{i}, \beta+\left(v_{i}-u_{i}\right)$

Dimana $\mathrm{i}=1,2,3 \ldots, \mathrm{n}$

Random error, $v_{i}$ untuk menghitung ukuran kesalahan dan faktor acak lainnya seperti cuaca, dan lain-lain, bersama-sama dengan efek kombinasi dari variabel input yang tidak terdefinisi di fungsi produksi. Variabel $v_{i}$ merupakan variabel acak yang bebas dan secara identik terdistribusi normal (independent-identically distributed atau i.i.d) dengan rataan bernilai nol dan ragamnya diasumsikan i.i.d eksponensial atau variabel acak setengah normal (half-normal variabels). Variabel $u_{i}$ berfungsi untuk menangkap efek inefisiensi teknis yang merefleksikan komponen galat (error) yang sifatnya internal. Variabel ui juga merupakan variabel acak non negatif dengan sebaran bersifat setengah normal.

Persamaan (1) disebut sebagai fungsi produksi stochastic frontier karena nilai output dibatasi oleh variabel acak (stochastic) yaitu nilai harapan dari $\mathrm{x}_{\mathrm{i}} \beta+\mathrm{v}_{\mathrm{i}}$ atau $\exp \left(x_{i} \beta+v_{i}\right)$. Random error bernilai negatif atau positif dan begitu juga output stochastic frontier bervariasi sekitar bagian tertentu dari model deterministic frontier, $\exp \left(x_{i} \beta\right)$. Komponen deterministik dari model frontier, $y=\exp \left(x_{i} \beta\right)$, mengasumsikan bahwa berlaku hukum diminishing return to scale. Petani yang menghasilkan output aktual di bawah produksi deterministic frontier, namun output stochastic frontier-nya melampaui dari output deterministiknya, maka hal ini dapat terjadi karena aktivitas produksi petani tersebut dipengaruhi oleh kondisi yang menguntungkan (misalnya curah hujan yang cukup, sinar matahari yang memadai, tidak adanya 
serangan hama dan penyakit) dimana variabel $v_{i}$ bernilai positif. Petani yang menghasilkan output aktual dibawah produksi deterministic frontier, dan demikian pula output stochastic frontier-nya berada di bawah output deterministiknya dapat terjadi karena aktivitas produksi petani dipengaruhi oleh kondisi yang tidak menguntungkan dimana vi bernilai negatif (Coelli et al., 1998).

\section{WAKTU DAN LOKASI PENELITIAN}

Penelitian ini dilakukan di Kabupaten Solok Selatan. Pemilihan lokasi dilakukan dengan sengaja (purposive) dengan pertimbangan bahwa Kabupaten Solok Selatan merupakan salah satu sentra produksi padi berbasis SRI di Sumatera Barat. Kemudian Kecamatan Sungai Pagu dipilih sebagai kecamatan yang memiliki luas lahan dan produksi padi yang tinggi di Kabupaten Solok Selatan. Pelaksanaan penelitian dilakukan bulan Maret sampai April 2015.

\section{JENIS DAN SUMBER DATA}

Jenis data yang digunakan adalah data primer dan sekunder. Data primer berupa data cross section yang diperoleh melalui wawancara langsung dengan petani responden menggunakan kuisioner. Data sekunder diperoleh dari Badan Pusat Statistik, Dinas Pertanian, Peternakan dan Perikanan Kabupaten Solok Selatan, UPTD Pertanian Kec. Sungai Pagu dan berbagai tesis, disertasi serta jurnal yang relevan dengan penelitian.

Metode pengambilan sampel dilakukan dengan cara simple random sampling untuk petani yang menerapkan SRI pada usahatani padi dan purposive sampling untuk petani yang tidak menerapkan SRI pada usahatani padi. Jumlah petani responden dalam penelitian ini adalah 60 orang petani padi SRI dan 30 orang petani non SRI/ konvensional.

\section{METODE ANALISIS DATA}

\section{Analisis Statistik Metode Probit}

Analisis statistik metode probit digunakan untuk penentuan faktor-faktor yang berpengaruh terhadap keputusan petani untuk mengikuti program SRI. Peubah tak bebas yang digunakan untuk model probit yaitu keputusan petani dalam mengikuti program SRI pada usahatani padinya. Peubah tak bebas berupa $Y=1$ (mengikuti program SRI) dan $Y=0$ (tidak mengikuti program SRI). penyelesaian metode ini menggunakan bantuan komputer dengan program Eviews versi 7. Model persamaan regresinya sebagai berikut:

$Y i=\beta_{0}+\beta_{1} X_{1}+\beta_{2} X_{2}+\beta_{3} X_{3}+\beta_{4} X_{4}+\beta_{5} X_{5}+\beta_{6} X_{6}$ $+\beta_{7} X_{7}$.

Keterangan :

$\mathrm{Y}=$ keputusan petani mengikuti program (1=mengikuti program, 0 =tidak mengikuti program)

$\mathrm{X}_{1}=$ umur petani (tahun)

$\mathrm{X}_{2}=$ luas lahan (ha)

$\mathrm{X}_{3}=$ pendapatan non usahatani $(\mathrm{Rp})$

$\mathrm{X}_{4}=$ pengalaman usahatani padi (tahun)

$\mathrm{X}_{5}=$ lama menjadi anggota kelompok tani (tahun)

$\mathrm{X}_{6}=$ pendidikan formal (tahun)

$\mathrm{X}_{7}=$ frekuensi penyuluhan (kali/musim)

Tanda dan parameter yang diharapkan adalah $\beta_{1}, \beta_{2}, \beta_{3}, \beta_{4}, \beta_{5}, \beta_{6}, \beta_{7}>0$

\section{Analisis Fungsi Produksi dan Efisiensi Usahatani}

Efisiensi produksi dalam penelitian ini menggunakan fungsi produksi stochastic frontier. Dalam fungsi produksi faktor-faktor yang diduga mempengaruhi produksi adalah lahan, benih, pupuk urea, pupuk ponska (NPK), pupuk organik dan tenaga kerja. Model fungsi produksi stochastic frontier untuk usahatani padi sebagai berikut :

$$
\begin{aligned}
& \operatorname{Ln} Y=\beta_{0}+\beta_{1} \ln X_{1}+\beta_{2} \ln X_{2}+\beta_{3} \ln X_{3}+\beta_{4} \ln X_{4}+ \\
& \beta_{5} \ln X_{5}+\beta_{6} \ln X_{6}+(v i-u i) \text {. }
\end{aligned}
$$

Keterangan :

$\mathrm{Y}=$ produksi padi $(\mathrm{kg})$

$\mathrm{X}_{1}=$ luas lahan (ha)

$X_{2}=$ jumlah benih $(\mathrm{kg})$

$X_{3}=$ jumlah pupuk urea $(\mathrm{kg})$

$\mathrm{X}_{4}=$ jumlah pupuk ponska/NPK $(\mathrm{kg})$

$\mathrm{X}_{5}=$ jumlah pupuk organik $(\mathrm{kg})$

$\mathrm{X}_{6}=$ jumlah tenaga kerja $(\mathrm{HOK})$ 
(vi-ui) $=$ efek inefisensi teknis dalam model

Tanda dan besaran parameter yang diharapkan adalah $\beta_{1}, \beta_{2}, \beta_{3}, \beta_{4}, \beta_{5}, \beta_{6}, \beta_{7}>0$.

Analisis efisiensi teknis dapat diukur dengan menggunakan rumus sebagai berikut (Coelli et al., 1998):

$T E_{i}=\exp (-E[u i \mid \epsilon i]) i=1,2, \ldots, n$

Dimana $\mathrm{TE}_{\mathrm{i}}$ adalah efisiensi teknis petani ke-i, exp(-E[ui|ei]) adalah nilai harapan (mean) dari ui dengan syarat $\epsilon i$. Nilai efisiensi teknis $0 \leq \mathrm{TE}_{\mathrm{i}} \leq 1$. Nilai efisiensi teknis tersebut berhubungan terbalik dengan nilai efek inefisiensi teknis. Model efisiensi teknis yang digunakan dalam penelitian ini mengacu pada model efek inefisiensi teknis yang dikembangkan oleh Bettese dan Coelli (1998).

Random error, $\mathrm{v}_{\mathrm{i}}$, berguna untuk menghitung ukuran kesalahan dan faktor acak lainnya seperti cuaca, dan lain-lain, bersama-sama dengan efek kombinasi dari variabel input yang tidak terdefinisi di fungsi produksi. Variabel $v_{i}$ merupakan variabel acak yang bebas dan secara identik terdistribusi normal (independent-identically distributed atau i.i.d) dengan rataan bernilai nol dan ragamnya konstan, $\sigma^{2}$ atau $\mathrm{N}\left(\left(\mu i, \sigma^{2}\right)\right)$. Variabel ui diasumsikan i.i.d. eksponensial atau variabel acak setengah normal (halfnormal variables). Variabel $\mathrm{u}_{\mathrm{i}}$, berfungsi untuk menangkap efek inefisiensi teknis. Untuk menentukan nilai parameter distribusi $\left(\mu_{\mathrm{i}}\right)$ efek inefisiensi teknis pada penelitian ini digunakan rumus :

$U_{i}=\delta_{0}+\delta_{1} Z_{1}+\delta_{2} Z_{2}+\delta_{3} Z_{3}+\delta_{4} Z_{4}+\omega_{1} D_{1}+\omega_{2} D_{2} \ldots$ (5)

Keterangan :

$\mathrm{U}_{\mathrm{i}}=$ efek inefisiensi teknis

$Z_{1}=$ umur petani padi (tahun)

$\mathrm{Z}_{2}=$ tingkat pendidikan (tahun)

$Z_{3}=$ frekuensi penyuluhan (kali/musim)

$Z_{4}=$ jumlah anggota keluarga (orang)

$\mathrm{D}_{1}=$ dummy kepemilikan lahan (milik sendiri= 1 dan lahan sakap $=0$ )

$\mathrm{D}_{2}=$ dummy status usahatani (pencaharian utama=1 dan bukan pencaharian utama $=0$ )
Tanda dan besaran parameter yang diharapkan $\delta_{1}, \delta_{2}, \delta_{3}, \delta_{4}, \omega_{1}, \omega_{2}<0$.

Dalam mengukur efisiensi alokatif dan ekonomi terlebih dahulu diturunkan fungsi biaya dual dari fungsi produksi CobbDouglas yang homogen (Debertin 1986). Asumsi yang digunakan adalah bentuk fungsi produksi cobb-douglas dengan menggunakan dua input sebagai berikut :

$Y=\beta_{0} X_{1} \beta 1 X_{2}{ }^{\beta 2}$

Dan fungsi biaya inputnya adalah

$\mathrm{C}=\mathrm{P}_{1} \mathrm{X}_{1}+\mathrm{P}_{2} \mathrm{X}_{2}$

Bentuk fungsi biaya dual dapat diturunkan dengan menggunakan asumsi minimisasi biaya dengan kendala output $\mathrm{Y}=\mathrm{Y}_{0}$. Untuk memperoleh fungsi biaya dual harus diperoleh nilai expansion path (perluasan skala usaha) yang dapat diperoleh melalui fungsi langrange sebagai berikut :

$L=P_{1} X_{1}+P_{2} X_{2}+\lambda\left(Y-\beta_{0} X_{1}^{\beta 1} X_{2}{ }^{\beta 2}\right)$

Untuk memperoleh nilai $\mathrm{x}_{1}$ dan $\mathrm{x}_{2}$ expansion path fungsi langrange di turunkan pada firstorder condition sebagai berikut :

$\frac{\mathrm{dL}}{\mathrm{dX}}=\mathrm{P}_{1}-\lambda \beta_{0} \beta_{1} \mathrm{X}_{1}^{\beta_{1}-1} \mathrm{X}_{2}^{\beta_{2}}=0$

$\frac{\mathrm{dL}}{\mathrm{d} \mathrm{X}_{2}}=\mathrm{P}_{2}-\lambda \beta_{0} \beta_{2} \mathrm{X}_{1}^{\beta_{1}} \mathrm{X}_{2} \beta_{2}^{-1}=0$

$\frac{\mathrm{dL}}{\mathrm{d} \lambda}=\mathrm{Y}-\beta_{0} \mathrm{X}_{1}{ }^{\beta_{1}} \mathrm{X}_{2}{ }^{\beta_{2}}=0$

Dari persamaan (8) dan (9) diperoleh nilai $X_{1}$ dan $\mathrm{X}_{2}$ expansion path yaitu :

$X_{1}=\left(\frac{P_{2}}{P_{1}}\right)\left(\frac{\beta_{1}}{\beta_{2}}\right) X_{2}$

$X_{2}=\left(\frac{P_{1}}{P_{2}}\right)\left(\frac{\beta_{2}}{\beta_{1}}\right) X_{1}$

Setelah itu persamaan (13) disubstitusikan ke persamaan (11) menjadi : 
$Y=\beta_{0} X_{1} \beta_{1}\left[\left(\frac{P_{1}}{P_{2}}\right)\left(\frac{\beta_{2}}{\beta_{1}}\right) X_{1}\right]^{\beta_{2}}$

$Y=\beta_{0} X_{1}^{\beta_{1}} P_{1} \beta_{2} P_{2}{ }^{-\beta_{2}} \beta_{2}^{\beta_{2}} \beta_{1}^{-\beta_{2}} X_{1}^{\beta_{2}}$

$X_{1} \beta_{1}+\beta_{2}=\frac{Y}{\beta_{0} P_{1}{ }^{\beta_{2}} \mathrm{P}_{2}^{-\beta_{2}} \beta_{2}^{\beta_{2}} \beta_{1}^{-\beta_{2}}}$

Dari persamaan (14) maka fungsi permintaan input untuk $X_{1}$ dan $X_{2}$ dapat ditentukan yaitu

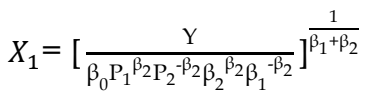

$X_{2}=\left[\frac{Y}{\beta_{0} \mathrm{P}_{2}{ }^{\beta_{1}} \mathrm{P}_{1}^{-\beta_{1}} \beta_{1}^{\beta_{1} \beta_{2}{ }^{-\beta_{1}}}}\right]^{\frac{1}{\beta_{1}+\beta_{2}}}$

Untuk mendapatkan fungsi biaya dual frontier maka persamaan $\mathrm{x}_{1}$ dan $\mathrm{x}_{2}$ disubstitusikan ke dalam persamaan biaya (7) yaitu :

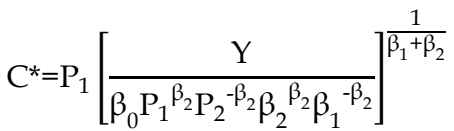

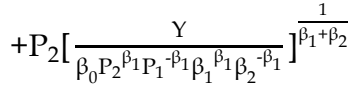

Menurut Jondrow et al. (1982), efisiensi ekonomi (EE) didefinisikan sebagai rasio antara biaya total produksi minimum yang diobservasi $\left(C^{*}\right)$ dengan total biaya produksi aktual (C), seperti terlihat pada persamaan berikut :

$\mathrm{EE}=\frac{\mathrm{C}^{*}}{\mathrm{C}}=\frac{\mathrm{E}\left(\mathrm{C}_{\mathrm{i}} \mid \mathrm{u}_{\mathrm{i}}=0, \mathrm{Y}_{\mathrm{i}}, \mathrm{P}_{\mathrm{i}}\right.}{\mathrm{E}\left(\mathrm{C}_{\mathrm{i}} \mid \mathrm{u}_{\mathrm{i}}, \mathrm{Y}_{\mathrm{i}}, \mathrm{P}_{\mathrm{i}}\right)}=\mathrm{E}\left[\exp \cdot\left(\mathrm{U}_{\mathrm{i}} / \varepsilon\right)\right]$
Efisiensi ekonomi merupakan gabungan antara efisiensi teknis dan efisiensi alokatif sehingga efisiensi alokatif (AE) dapat diperoleh dengan persamaan :

$\mathrm{AE}=\frac{\mathrm{EE}}{\mathrm{TE}}$

dimana $\mathrm{AE}$ bernilai $0 \leq \mathrm{AE} \leq 1$ dan $\mathrm{EE}$ bernilai $0 \leq \mathrm{EE} \leq 1$.

\section{HASIL DAN PEMBAHASAN}

\section{FAKTOR SOSIAL EKONOMI PENENTU PENERAPAN SRI (SYSTEM OF RICE INTENSIFICATION) PADA USAHATANI PADI}

Untuk menentukan faktor sosial ekonomi yang mempengaruhi penerapan SRI pada usahatani padi di Kabupaten Solok Selatan di analisis menggunakan model regresi probit. Variabel independen dalam model regresi probit ini terdiri dari 7 variabel yaitu umur petani padi, luas lahan, pendapatan non usahatani, pengalaman usahatani padi, lama menjadi anggota kelompok tani, pendidikan formal petani dan frekuensi penyuluhan. Hasil pendugaan faktor-faktor yang mempengaruhi keputusan petani dalam menerapkan SRI pada usahatani padi dapat disajikan pada Tabel 1.

Secara umum ada 3 variabel sosial ekonomi yang berpengaruh nyata terhadap peluang keputusan petani untuk mengikuti program padi berbasis SRI. Nilai LR Statistic sebesar 60,767 dengan tingkat probabilitas ( $L R$

Tabel 1. Hasil Pendugaan Faktor Sosial Ekonomi yang Menentukan Keputusan Petani untuk Mengikuti Program SRI di Kabupaten Solok Selatan

\begin{tabular}{|c|c|c|}
\hline Faktor sosial ekonomi & Koefisien & Probabilitas \\
\hline Konstanta & $-1,1439$ & 0,4373 \\
\hline Umur petani padi $\left(X_{1}\right)$ & $-0,02217$ & 0,5046 \\
\hline Luas lahan $\left(X_{2}\right)$ & $2,6701^{*}$ & 0,0327 \\
\hline Pendapatan non usahatani $\left(X_{3}\right)$ & $-3,09 E-07$ & 0,3391 \\
\hline Pengalaman usahatani padi $\left(X_{4}\right)$ & 0,0288 & 0,4034 \\
\hline Lama menjadi anggota kelompok tani $\left(X_{5}\right)$ & $0,1592^{*}$ & 0,0497 \\
\hline Pendidikan formal $\left(\mathrm{X}_{6}\right)$ & 0,0222 & 0,7794 \\
\hline Frekuensi penyuluhan $\left(X_{7}\right)$ & $0,2470^{* *}$ & 0,0005 \\
\hline McFadden R-Squared & 0,5303 & \\
\hline LR Statistic & 60,767 & \\
\hline Prob (LR Statistic) & 0,0000 & \\
\hline
\end{tabular}

Keterangan : ** nyata pada taraf a 0,$01 ;$ * nyata pada taraf $a=0,05$ 
Statistic) 0,000, artinya ada variabel sosial ekonomi yang berpengaruh nyata terhadap peluang keputusan petani padi untuk mengikuti program padi berbasis SRI. nilai McFadden R-Squared sebesar 0,5303 maka variabel bebas dalam model probit diatas sudah cukup baik untuk menjelaskan variabel tak bebasnya.

Variabel luas lahan mempunyai koefisien yang bernilai positif $(2,6701)$ dan signifikan $(0,0327)$, maka luas lahan akan mempengaruhi besar keputusan petani untuk mengikuti program padi berbasis SRI, dimana varibel-variabel lainnya dianggap tetap. Dapat disimpulkan bahwa semakin luas lahan yang dikelola oleh petani maka akan meningkatkan peluang petani untuk mengikuti program padi berbasis SRI. Hasil analisis ini berbeda dengan temuan Ishak dan Afrizon (2011), Simanhuluk et al. (2011) yang mengemukakan bahwa luas penguasaan lahan mempunyai nilai koefisien yang negatif dan tidak berpengaruh secara nyata terhadap penerapan teknologi SRI di Kabupaten Seluma.

Variabel lama menjadi kelompok tani mempunyai nilai koefesien yang positif $(0,1592)$ dan signifikan $(0,0497)$, artinya semakin lama petani menjadi anggota salah satu kelompok tani maka akan meningkatkan peluang petani untuk mengikuti program padi berbasis SRI dari pada petani yang tidak menjadi anggota kelompok tani. Kajian lapangan menunjukkan bahwa petani yang tergabung didalam sebuah kelompok tani dan petani tersebut aktif dalam keanggotaan maka petani tersebut pasti mendapatkan dorongan oleh sesama anggota kelompok tani untuk menerapkan program padi berbasis SRI. Pertemuan antara anggota kelompok tani rata-rata dalam satu bulannya rutin mengadakan pertemuan sebanyak dua kali. Pertemuan anggota kelompok membahas tentang evaluasi kemajuan dan keberhasilan anggota didalam usahatani padinya. Sehingga terdapat suatu pembelajaran bagi petani yang tergabung didalam sebuah kelompok tani.
Variabel berikutnya yang mempunyai nilai positif $(0,2470)$ dan signifikan $(0,0005)$ adalah frekuensi penyuluhan. Banyaknya frekuensi penyuluhan akan mendorong petani untuk memutuskan mengikuti program padi berbasis SRI. Petani diberikan penyuluhan dan pendampingan oleh lembaga penyuluhan pertanian dan lembaga penelitian. Pada pendampingan dan penyuluhan sekolah lapang, petani dan tenaga penyuluh secara rutin mengadakan pertemuan kelompok dan juga aksi demonstrasi plot (demplot) dibeberapa lokasi sebagai contoh cara memilih benih yang baik sehingga petani lebih cepat memahami dan praktek langsung dalam setiap penerapan program padi berbasis SRI.

\section{ANALISIS FUNGSI PRODUKSI STOCHASTICS FRONTIER USAHATANI PADI DENGAN METODE MLE}

Fungsi produksi Cobb-Douglas digunakan sebagai analisis model fungsi produksi stochastic frontier pada penelitian ini. Fungsi produksi ini terdiri dari 6 variabel penjelas yaitu luas lahan, benih, pupuk ponska/NPK, pupuk urea, pupuk organik, dan tenaga kerja. Hasil pendugaan fungsi produksi disajikan pada Tabel 2.

Hasil metode MLE juga menggambarkan nilai sigma square $\left(\sigma^{2}\right)$ dan parameter gamma $(\gamma)$ dari model efek inefisiensi teknis fungsi produksi stochastic frontier pada usahatani padi berbasis SRI dan non SRI. Nilai gamma berturut-turut pada usahatani padi berbasis SRI dan non SRI sebesar 0,90 dan 0,99 . Nilai kedua gamma ini mendekati satu, hal ini menunjukkan bahwa error term hanya berasal dari efek inefisiensi $\left(u_{i}\right)$ dan bukan berasal dari akibat noise $\left(\mathrm{v}_{\mathrm{i}}\right)$. Nilai sigma squared berturut-turut sebesar 0,19 dan 0,03. Nilai tersebut mendekati nol sehingga error term inefisiensi pada usahatani padi berbasis SRI dan non SRI terdistribusi secara normal. Sedangkan nilai rasio generalized-likelihood (LR) fungsi produksi padi berbasis SRI sebesar 15,37 masih lebih besar dari nilai tabel Kodde dan Palm sebesar 14,85 yang nyata 
Tabel 2. Hasil Pendugaan Fungsi Produksi dengan Metode MLE pada Usahatani Padi Berbasis SRI dan Non SRI di Kabupaten Solok Selatan

\begin{tabular}{|c|c|c|c|c|}
\hline \multirow{2}{*}{ Uraian } & \multicolumn{2}{|c|}{ SRI } & \multicolumn{2}{|c|}{ Non SRI } \\
\hline & Koefisien & t-ratio & Koefisien & t-ratio \\
\hline Konstanta & 6,85 & 23,01 & 7,17 & 37,08 \\
\hline Lahan $\left(\mathbf{X}_{1}\right)$ & $0,71^{* * * *}$ & 14,20 & $0,75^{* * * *}$ & 15,47 \\
\hline Benih $\left(X_{2}\right)$ & 0,03 & 0,63 & $0,06^{* *}$ & 1,59 \\
\hline Pupuk ponska/NPK $\left(X_{3}\right)$ & $0,06^{* * *}$ & 2,23 & $0,11^{* * * *}$ & 3,38 \\
\hline Pupuk urea $\left(X_{4}\right)$ & $0,04^{*}$ & 1,08 & $0,07^{* \star *}$ & 2,12 \\
\hline Pupuk organik $\left(X_{5}\right)$ & $0,11^{* * * *}$ & 2,78 & 0,00 & 0,98 \\
\hline Tenaga kerja $\left(X_{6}\right)$ & $0,10^{* * *}$ & 1,96 & 0,03 & 0,60 \\
\hline Sigma-square & 0,19 & & 0,03 & \\
\hline Gamma & 0,90 & & 0,99 & \\
\hline LR-test & 15,37 & & 15,39 & \\
\hline Log likelihood MLE & 16,32 & & 34,84 & \\
\hline
\end{tabular}

pada taraf 5 persen dan nilai rasio LR pada usahatani padi non SRI sebesar 15,39 masih lebih besar dari nilai tabel Kodde dan Palm sebesar 14,85 yang nyata pada taraf 5 persen. Hal ini berarti bahwa terdapat pengaruh efisiensi dan inefisiensi teknis petani padi di Kabupaten Solok Selatan.

Hasil pendugaan dengan metode MLE pada Tabel 2 diketahui bahwa koefisien setiap variabel semuanya bernilai positif dan sesuai dengan yang diharapkan. Nilai pendugaan parameter pada fungsi produksi stochastic frontier dapat menunjukkan nilai elastisitas dari input-input yang digunakan. Variabelvariabel input yang berpengaruh secara nyata terhadap produksi padi berbasis SRI di Kabupaten Solok Selatan adalah luas lahan, pupuk ponska, pupuk urea, pupuk organik dan tenaga kerja.

Nilai koefisien yang paling besar baik pada usahatani padi berbasis SRI dan non SRI adalah luas lahan, besarnya berturut-turut 0,71 dan 0,75. Luas lahan berpengaruh nyata pada taraf a 1 persen yang mengindikasikan bahwa kontribusi dalam total faktor produktivitas adalah dominan dan variabel lahan yang paling responsif dari pada variabel lainnya. Jika luas lahan bertambah satu persen dengan input lainnya tetap maka produksi padi meningkat sebesar 0,71 persen dan 0,75 persen. Penelitian ini sejalan dengan penelitian Akinbode et al. (2011), Nikhil and Azeez (2011), Tadesse and Krishnamoorthy
(1997) yang mengemukakan bahwa lahan berpengaruh positif dan nyata terhadap produksi padi. Hasil analisis menunjukkan bahwa produksi padi sangat responsif terhadap luas lahan dan merupakan faktor dominan dari produksi padi di Kabupaten Solok Selatan. Rata-rata penggunaan lahan petani padi berbasis SRI lebih luas dibandingkan dengan petani yang tidak menerapkan SRI, luas lahan yang dikuasai petani SRI bernilai 0,56 hektar dan 0,27 hektar pada petani padi non SRI. Penambahan lahan pertanian dapat meningkatkan produksi padi, namun usaha untuk melakukan penambahan lahan tidak memungkinkan didaerah penelitian, sehingga salah satu cara untuk meningkatkan produksi padi harus dilakukan dengan cara intensifikasi yakni melalui teknologi SRI pada usahatani padi.

Elastisitas variabel benih pada fungsi produksi usahatani berbasis SRI dengan metode MLE bernilai rendah yakni 0,03 dan tidak signifikan. Namun elastisitas variabel benih pada fungsi produksi usahatani non SRI bernilai lebih besar dan signifikan pada taraf a 10 persen dari pada usahatani padi yang berbasis SRI, nilai nya adalah 0,06. Hal ini mengindikasikan bahwa penambahan benih pada usahatani padi berbasis SRI tidak akan meningkatkan produksi padi, sedangkan penambahan benih sebesar satu persen pada usahatani padi non SRI dengan input lainnya yang tetap maka produksi padi pada 
usahatani non SRI bertambah sebesar 0,06 persen. Hasil penelitian ini sejalan dengan penelitian Hasnain (2015), Akinbode et al. (2011) yang mengemukakan bahwa benih berpengaruh positif dan nyata terhadap produksi padi. Pada daerah penelitian, benih yang digunakan oleh petani responden sangatlah berbeda dari segi kualitas dan kuantitas tetapi sama dalam varietas, petani padi SRI menggunakan benih unggul bersetifikat sedangkan petani padi non SRI cenderung menggunakan benih yang berasal dari musim panen sebelumnya sehingga akan mempengaruhi banyaknya benih yang digunakan pada usahatani padi. Rata-rata penggunaan benih pada usahatani padi berbasis SRI sebesar $32,12 \mathrm{~kg} / \mathrm{ha}$ dan pada usahatani padi non SRI sebesar 96,67 kg/ha. Penggunaan benih yang tinggi pada usahatani padi non SRI disebabkan karena benih yang digunakan tidak melalui tes dan seleksi benih sehingga akan mempengaruhi jumlah benih yang bisa tumbuh. Selain itu penggunaan benih yang tinggi juga disebabkan oleh penggunaan jumlah bibit yang ditanam per lobangnya yakni berkisar antara 15-20 bibit per lobang tanam. Jenis benih yang digunakan oleh petani responden adalah Junjung, Ganda pulau, Anak Daro, Bakwan dan Batang Pasaman.

Elastisitas variabel pupuk ponska dengan metode MLE pada usahatani padi berbasis SRI mempunyai nilai elastisitas sebesar 0,06 dan nyata pada taraf a 5 persen dan juga pada usahatani padi non SRI variabel pupuk ponska bernilai lebih besar jika dibandingkan dengan padi berbasis SRI yakni sebesar 0,11 dan signifikan pada taraf a 1 persen. Penelitian Akinbode et al. (2011), Alhassan (2008), Tadesse and Krishnamoorthy (1997) juga menemukan bahwa pupuk berpengaruh positif dan nyata terhadap produksi padi. Dalam pemupukan tanaman, ada perlakuan yang berbeda antar kedua kelompok petani responden ini, perbedaan ini terlihat dari rata-rata penggunaan pupuk ponska oleh petani padi SRI sebanyak 36,68 $\mathrm{kg} /$ ha dan pada petani padi non SRI sebesar $34,32 \mathrm{~kg} / \mathrm{ha}$.
Pupuk urea mempunyai elastisitas yang positif dan bernilai kecil tapi pada kedua jenis usahatani sama-sama signifikan pada taraf yang berbeda. Elastisitas pupuk urea pada usahatani padi berbasis SRI sebesar 0,04 dan signifikan pada taraf a 15 persen. Sedangkan pada usahatani padi non SRI nilai elastisitas variabel pupuk urea bernilai 0,07 dan signifikan pada taraf 5 persen. Hasil analisis dilapangan menemukan bahwa rata-rata penggunaan pupuk urea oleh petani padi SRI jauh lebih rendah dibandingkan dengan petani padi non SRI. Petani padi SRI menggunakan pupuk urea sebanyak 60,60 $\mathrm{kg} /$ ha sedangkan pada petani padi non SRI menggunakan pupuk urea sebanyak 95,69 $\mathrm{kg} / \mathrm{ha}$.

Beda halnya dengan elastisitas pupuk organik yang hanya signifikan pada usahatani padi SRI. Namun nilai elastisitasnya masih sangat rendah yaitu 0,11 yang signifikan pada taraf a 1 persen. Artinya variabel pupuk organik berpengaruh nyata pada usahatani padi SRI dimana setiap penambahan 1 persen pupuk organik maka akan meningkatkan produksi padi sebesar 0,11 persen. Penggunaan pupuk organik merupakan komponen penting yang di isyaratkan dalam teknologi SRI, sehingga penggunaan pupuk organik pada usahatani padi SRI secara statistik menunjukkan perbedaan yang sangat nyata. Rata-rata penggunaan pupuk organik pada usahatani padi SRI adalah 1.046,18 $\mathrm{kg} / \mathrm{ha}$, nilai ini jauh lebih tinggi dari penggunaan pupuk organik oleh petani padi non SRI yang bernilai $339,48 \mathrm{~kg} /$ ha nya.

Variabel terakhir yang mempunyai nilai elastisitas positif adalah variabel tenaga kerja. Elastisitas tenaga kerja signifikan pada taraf a 5 persen dengan nilai elastisitasnya 0,10 . Hasil analisis ini sejalan dengan penelitian Hasnain (2015), Akinbode et al. (2011), Nikhil and Azeez (2011), Al-hassan (2008), Tadesse and Krishnamoorthy (1997) yang menemukan bahwa tenaga kerja mempunyai koefisien yang positif dan nyata terhadap produksi padi. Sedangkan pada usahatani padi non SRI bernilai positif namun tidak berpengaruh terhadap peningkatan produktivitas padi 
didaerah penelitian. Usahatani padi SRI ratarata menggunakan tenaga kerja 26,31 HOK/ha dan usahatani padi non SRI rata-rata menggunakan tenaga kerja sebesar 48,55 HOK/ha. Rendahnya penggunaan tenaga kerja pada usahatani padi SRI disebabkan oleh adanya efisiensi tenaga kerja dalam proses persemaian benih, penanaman bibit, penyiangan dan pemeliharaan tanaman pada usahatani.

Penjumlahan koefisien elastisitas pada usahatani padi SRI adalah 1,05. Ini berarti skala produksi usahatani padi SRI di Kabupaten Solok Selatan berada pada keadaan Constant Return to Scale (CRS). Sedangkan penjumlahan elastisitas pada usahatani padi non SRI adalah 1,02, artinya usahatani padi non SRI di Kabupaten Solok Selatan juga berada pada skala Constant Return to Scale (CRS). Dengan kata lain, jika penggunaan masing-masing input produksi mengalami peningkatan sebesar 1 persen secara proporsional maka produksi padi akan meningkat sebesar 1,05 persen pada usahatani padi SRI dan 1,02 persen pada usahatani padi non SRI.

\section{EFISIENSI TEKNIS, ALOKATIF DAN EKONOMI USAHATANI PADI DI KABUPATEN SOLOK SELATAN}

Efisiensi teknis dianalisis menggunakan model fungsi produksi stochastic frontier dengan metode estimasi Maximum Likelihood Estimate (MLE) dengan program frontier 4.1 sedangkan tingkat efisiensi alokatif dan ekonomi dianalisis dengan menggunakan dual cost frontier. Adapun hasil analisis efisiensi teknis, alokatif dan ekonomi dapat dilihat pada Tabel 3 .

Hasil analisis menunjukkan bahwa usahatani padi berbasis SRI dan non SRI secara teknis sudah efisien, nilai rata-rata efisiensi teknis pada usahatani padi berbasis SRI adalah 0,88 dengan nilai efisiensi minimum 0,40 dan nilai efisiensi maksimum 0,96 . Sedangkan pada usahatani padi non SRI rata-rata efisiensi teknisnya adalah 0,89 dengan nilai efisiensi minimum 0,69 dan nilai efisiensi maksimum 0,99. Hasil tersebut menunjukkan bahwa di daerah penelitian secara keseluruhan petani masih dapat meningkatkan efisiensi teknis pada tingkat teknologi dan input yang ada sebesar 8,33 persen $(1-0,88 / 0,96)$ pada SRI dan 10,10 persen $(1-0,89 / 0,99)$ pada petani non SRI. Secara umum petani responden baik petani padi berbasis SRI maupun petani padi non SRI telah efisien secara teknis karena rata-rata efisiensi teknisnya besar dari 0,8. Perbedaan tingkat efisiensi teknis yang dicapai petani padi mengindikasikan tingkat penguasaan dan aplikasi teknologi yang berbeda-beda. Dilihat dari segi produktivitas, usahatani padi SRI mampu menghasilkan produktivitas padi rata-rata sebesar 3.927,48 $\mathrm{kg} / \mathrm{ha}$ dan usahatani padi non SRI menghasilkan produktivitas padi rata-rata sebesar 3.402,92 $\mathrm{kg} /$ ha. Menurut Fadwiwati (2014), perbedaan

Tabel 3. Sebaran Frekuensi Efisiensi Teknis, Alokatif dan Ekonomi Usahatani Padi Berbasis SRI dan Non SRI di Kabupaten Solok Selatan

\begin{tabular}{|l|r|r|r|r|r|r|}
\hline \multicolumn{1}{|c|}{ Kisaran } & \multicolumn{2}{c|}{ Efisiensi Teknis } & \multicolumn{2}{c|}{ Efisiensi Alokatif } & \multicolumn{2}{c|}{ Efisiensi Ekonomi } \\
\hline $\mathbf{4}$ & SRI & Non SRI & SRI & Non SRI & SRI & Non SRI \\
\hline $\mathbf{3 0}$ & 0 & 0 & 7 & 4 & 14 & 5 \\
\hline $\mathbf{0 , 3 1 - 0 , 4 0}$ & 1 & 0 & 20 & 9 & 30 & 18 \\
\hline $\mathbf{0 , 4 1 - 0 , 5 0}$ & 0 & 0 & 28 & 12 & 14 & 5 \\
\hline $\mathbf{0 , 5 1 - 0 , 6 0}$ & 0 & 0 & 3 & 4 & 2 & 2 \\
\hline $\mathbf{0 , 6 1 - 0 , 7 0}$ & 2 & 1 & 1 & 0 & 0 & 0 \\
\hline $\mathbf{0 , 7 1 - 0 , 8 0}$ & 7 & 6 & 0 & 1 & 0 & 0 \\
\hline $\mathbf{0 , 8 1 - 0 , 9 0}$ & 21 & 7 & 0 & 0 & 0 & 0 \\
\hline $\mathbf{>} \mathbf{0 , 9 0}$ & 29 & 16 & 1 & 0 & 0 & 0 \\
\hline Maksimum & 0,96 & 0,99 & 0,92 & 0,77 & 0,51 & 0,53 \\
\hline Minimum & 0,40 & 0,69 & 0,21 & 0,26 & 0,17 & 0,24 \\
\hline Rata-rata & 0,88 & 0,89 & 0,41 & 0,42 & 0,36 & 0,37 \\
\hline
\end{tabular}


tingkat penguasaan teknologi dapat disebabkan oleh atribut yang melekat pada diri petani seperti pengalaman berusahatani, umur, dan pendidikan juga dapat disebabkan oleh faktor eksternal seperti penyuluhan.

Rata-rata efisiensi alokatif usahatani padi SRI di Kabupaten Solok Selatan sebesar 0,41 persen dengan nilai kisaran efisiensi alokatif dari 0,21 - 0,92, dan petani padi non SRI ratarata tingkat efisiensi alokatifnya sebesar 0,42 dengan nilai kisaran 0,26-0,77. Berdasarkan hasil analisis tersebut maka secara keseluruhan petani padi SRI masih belum efisien secara alokatif karena nilai rata-ratanya masih rendah. Untuk mencapai efisiensi alokatif yang maksimal maka petani SRI harus menghemat biaya sebesar $(1-0,41 / 0,92)$ atau sebesar 55,43 persen dan 45,45 persen pada petani non SRI.

Rata-rata efisiensi ekonomi pada usahatani padi berbasis SRI di Kabupaten Solok Selatan sebesar 0,36 dengan kisaran nilai efisiensi ekonomi 0,17 - 0,51. Pada petani padi non SRI sebesar 0,37 dengan nilai terendah sebesar 0,24 dan nilai tertinggi 0,53 hal ini menunjukkan bahwa secara ekonomi usahatani padi berbasis SRI di Kabupaten Solok Selatan belum efisien secara ekonomi. Jika petani ingin mencapai efisiensi ekonomi yang maksimum maka harus menghemat biaya sebesar $(1-0,36 / 0,51)$ atau sebesar 29,41 persen dan 30,19 persen pada petani non SRI.

Berdasarkan analisis efisiensi teknis, alokatif dan ekonomi usahatani padi SRI di Kabupaten Solok Selatan dapat dikatakan bahwa secara teknis petani sudah efisien dalam melakukan usahataninya. Akan tetapi secara alokatif dan ekonomi masih belum efisien. Tingginya nilai efisiensi teknis tidak di ikuti oleh nilai efisiensi alokatif dan ekonomi, hal ini disebabkan karena tingginya efisiensi dan produktivitas tidak diiringi dengan harga yang layak di pasar sehingga petani mengalokasikan input sesuai dengan kondisi keuntungan maksimum dan bukan berdasarkan produksi maksimum.

\section{INEFISIENSI TEKNIS USAHATANI PADI DI KABUPATEN SOLOK SELATAN}

Faktor-faktor yang mempengaruhi tingkat efisiensi teknis petani padi berbasis SRI yaitu jumlah anggota keluarga. Sedangkan pada usahatani padi non SRI dipengaruhi oleh variabel jumlah anggota keluarga, dummy status usahatani dan dummy status lahan. Hasil pendugaan model efek inefisiensi teknis pada usahatani padi berbasis SRI dan non SRI dapat dilihat pada Tabel 4.

Variabel jumlah anggota keluarga memiliki nilai koefisien positif pada petani padi berbasis SRI yaitu 0,17 dan berpengaruh nyata pada taraf a 10 persen terhadap inefisiensi teknis. Ini berarti semakin banyak anggota keluarga petani padi SRI akan menurunkan tingkat efisiensi teknis usahatani. Jumlah anggota keluarga akan mempengaruhi biayabiaya yang akan dikeluarkan untuk membeli input-input usahatani karena biaya yang tersedia akan dipakai untuk keperluan anggota keluarga petani. Hasil penelitian lapangan menemukan bahwa petani padi SRI cenderung menggunakan tenaga kerja luar keluarga yang telah memiliki pengetahuan mengenai proses budidaya padi SRI sehingga

Tabel 4. Hasil Pendugaan Faktor-Faktor yang Mempengaruhi Inefisiensi Teknis pada Usahatani Padi Berbasis SRI dan Non SRI di Kabupaten Solok Selatan

\begin{tabular}{|c|c|c|c|c|}
\hline \multirow{2}{*}{ Variabel } & \multicolumn{2}{|c|}{ SRI } & \multicolumn{2}{|c|}{ Non SRI } \\
\hline & Koefisien & $t$ - ratio & Koefisien & $t$ - ratio \\
\hline Konstanta & $-1,57$ & $-0,62$ & $-0,19$ & $-0,41$ \\
\hline Umur petani $\left(Z_{1}\right)$ & $-0,02$ & $-0,84$ & $-0,34$ & $-0,73$ \\
\hline Tingkat pendidikan $\left(\mathrm{Z}_{2}\right)$ & $-0,04$ & $-0,92$ & 0,18 & 0,91 \\
\hline Frekuensi penyuluhan $\left(\mathrm{Z}_{3}\right)$ & 0,03 & 0,74 & 0,12 & 0,96 \\
\hline Jumlah anggota keluarga $\left(\mathrm{Z}_{4}\right)$ & $0,17^{* *}$ & 1,33 & $-0,89^{* * *}$ & $-1,61$ \\
\hline Dummy status lahan $\left(Z_{5}\right)$ & 2,06 & 0,81 & $0,16^{*}$ & 1,24 \\
\hline Dummy status usahatani $\left(\mathrm{Z}_{6}\right)$ & $-0,99$ & $-0,89$ & $0,22^{* * *}$ & 1,89 \\
\hline
\end{tabular}


akan lebih efisien dalam kegiatan berusahatani padi. Petani padi SRI juga menggunakan tenaga kerja mesin seperti penggunaan mesin traktor sehingga akan mempermudah petani dalam proses budidaya padi SRI. Pada petani padi non SRI variabel jumlah anggota keluarga memiliki nilai koefisien yang negatif yakni -0,89 dan berpengaruh nyata pada taraf a 5 persen. Artinya variabel ini akan meningkatkan efisiensi atau menurunkan inefisiensi. Hasil ini sejalan dengan penelitian Goyal et al. (2006) bahwa variabel jumlah anggota keluarga berpengaruh negatif terhadap inefisiensi teknis usahatani padi di Haryana. Ukuran rumah tangga dapat di proxy kan sebagai jumlah tenaga kerja dalam keluarga. Semakin banyak anggota keluarga dalam rumah tangga seorang petani maka akan semakin banyak jumlah tenaga kerja yang dapat dilibatkan dalam kegiatan usahatani. Rata-rata penggunaan tenaga kerja dalam keluarga pada usahatani padi non SRI sebesar 1,11 HOK sehingga biaya yang seharusnya dikeluarkan untuk tenaga kerja luar keluarga dapat digunakan untuk penyediaan input-input produksi usahatani.

Dummy status lahan pada petani padi SRI bernilai positif terhadap inefisiensi dengan nilai koefisien 2,06 dan tidak berpengaruh nyata. Ini berarti status lahan akan meningkatkan inefisiensi atau menurunkan efisiensi, karena tidak signifikan maka status lahan dapat diabaikan. Hasil yang sama dalam penelitian Udayanganie et al. (2006) bahwa status lahan berpengaruh positif terhadap inefisiensi teknis usahatani padi di Srilanka. Namun pada petani padi non SRI dummy status lahan mempunyai nilai koefisien yang positif sebesar 0,16 dan berpengaruh nyata pada taraf a 15 persen, artinya status lahan milik menghasilkan efisiensi teknis yang lebih rendah dari pada lahan bukan milik atau sakap. Hal ini dikarenakan petani yang status lahannya merupakan lahan milik tidak memperhatikan tingkat produksi yang akan mereka dapatkan dan untung ruginya usahatani dapat mereka acuhkan. Lain halnya dengan petani padi yang lahannya merupakan lahan sakap, petani tersebut cenderung berhati-hati terhadap usahataninya, karena hasil produksi yang didapatkan dari usahataninya akan dibagi separuhnya dengan petani yang mempunyai lahan tersebut. Hasil ini berbeda dengan temuan Gupta et al. (2013) bahwa variabel status lahan berpengaruh negatif terhadap inefisiensi teknis usahatani padi di Hailakandi.

Dummy status usahatani pada petani padi SRI bernilai negatif sebesar $-0,99$ dan tidak berpengaruh nyata. Artinya status usahatani akan meningkatkan efisiensi atau menurunkan inefisiensi usahatani. Berbeda dengan petani padi non SRI, dummy status usahatani bernilai positif sebesar 0,22 dan berpengaruh nyata pada taraf a 5 persen. Artinya status usahatani padi sebagai pekerjaan utama menghasilkan efisiensi teknis yang lebih rendah dibandingkan dengan status sebagai pekerjaan sampingan pada petani non SRI. Kondisi lapangan menunjukkan bahwa petani dengan penghasilan utamanya adalah padi cenderung memiliki waktu yang banyak untuk melakukan aktivitas diusahataninya sehingga petani tersebut akan lebih efisiensi jika dibandingkan dengan petani yang status usahataninya sebagai pekerjaan sampingan. Petani padi SRI pada umumnya mempunyai pekerjaan utama sebagai petani padi, berbeda dengan petani padi non SRI yang mempunyai pekerjaan utamanya sebagai wiraswata sehingga mereka mempunyai waktu yang sangat terbatas diusahatani padi.

\section{KESIMPULAN DAN SARAN}

\section{KESIMPULAN}

Berdasarkan tujuan dan hasil pembahasan dalam penelitian ini maka dapat disimpulkan bahwa :

1. Penerapan usahatani padi berbasis SRI dipengaruhi oleh faktor luas lahan, lama menjadi anggota kelompok tani dan frekuensi penyuluhan.

2. Usahatani padi berbasis SRI dan non SRI di Kabupaten Solok Selatan telah efisien secara teknis, namun belum efisien 
secara alokatif dan ekonomi. Nilai ratarata efisiensi teknis, alokatif dan ekonomi pada usahatani padi berbasis SRI bernilai 0,88; 0,41; 0,36 dan 0,89; 0,42; 0,37 pada usahatani padi non SRI.

3. Faktor yang mempengaruhi inefisiensi teknis pada usahatani padi berbasis SRI adalah variabel jumlah anggota keluarga, sedangkan pada usahatani padi non SRI dipengaruhi oleh variabel jumlah anggota keluarga, dummy status lahan dan dummy status usahatani.

\section{SARAN}

1. Untuk pencapaian yang lebih maksimal dalam program SRI, pemerintah harus menjamin ketersedian input-input produksi melalui penyediaan pupuk urea dan ponska bersubsidi, dan penyediaan pupuk organik bersubsidi.

2. Pemerintah harus mendorong petanipetani melalui kelompok tani untuk dapat berpatisipasi dalam penerapan usahatani padi SRI.

\section{DAFTAR PUSTAKA}

Aigner, D., Lovell C. A. K., Schmidt, P. 1977. Formulation and Estimation of Stochastic Frontier Production Function Models. Journal of Econometrics 6(1): 21-37.

Akinbode, S.O., Dipeolu, A.O., and Ayinde, I.A. 2011. An Examination of Technical, Allocative and Economic Efficiencies in Ofada Rice Farming in Ogun State, Nigeria. African Journal of Agricultural Research. 6 (28):6027-6035.

Al-hassan, S. 2008. Technical Efficiency of Rice Farmers in Northen Ghana. African Economic Research Consortium. April 2008; Nairobi

Arifin, B. 2004. Analisis Ekonomi Pertanian Indonesia. Jakarta: Penerbit Buku Kompas.

Badan Pusat Statistik. 2014a. PDB Menurut Lapangan Usaha (Dinamis). Jakarta: Badan Pusat Statistik.
Badan Pusat Statistik. 2014b. Berita Resmi Statistik: Produksi Padi, Jagung dan Kedelai (Angka Ramalan I Tahun 2014). Jakarta: Badan Pusat Statistik.

Badan Pusat Statistik. 2014c. Sumatera Barat Dalam Angka 2014. Jakarta: Badan Pusat Statistik.

Battese, G. E., Coelli, T. J. 1995. A Model for Technical Inefficiency Effects in a Stochastic Frontier Production Function for Panel Data. Empirical Economics (20): 325- 332.

Coelli, T., Rao, D.S.P., Battese, G.E. 1998. An Introduction to Efficiency and Productivity Analysis. London: Kluwer Academic Publisher.

Darmadji. 2011. Analisis Kinerja Usahatani Padi Dengan Metode System of Rice Intensification (SRI) di Kabupaten Sleman Daerah Istimewa Yogyakarta. Jurnal Widya Agrika. 9(3):1-18.

Direktorat Pangan dan Pertanian. 2013. Rencana Pembangunan Jangka Menengah Nasional (RPJMN) Bidang Pangan dan Pertanian 2015-2019. Kementerian Perencanaan Pembangunan Nasional/Badan Perencanaan Pembangunan Nasional. Jakarta.

Debertin, D. L. 1986. Agricultural Production Economics. New York: Macmillan Publishing Company.

Djinis, Musdar, E., Sorel, D., Ismawardi, Elita, N., Sondang, Y., dan Ukrita, I. 2008. Penyuluhan dan Pembuatan Demontrasi Plot Penanaman Padi Metode The System of Rice Intensification (SRI). Journal Penelitian Lumbung. 7(1):28-35.

Fadwiwati, A.Y. 2013. Pengaruh Penggunaan Varietas Unggul Terhadap Efisiensi, Pendapatan dan Distribusi Pendapatan Petani Jagung di Provinsi Gorontalo [disertasi]. Bogor: Institut Pertanian Bogor.

Farrell, M. J. 1957. The Measurement of Productive Efficiency. Journal of Royal Statistic Society, Series A, 253-281.

Gupta, M., Ashish, T.R., Uttam, D., and Ritwik, M. 2013. Determinants of Technical Efficiency of Paddy 
Cultivators: A Study of Hailakandi District in Assam. Journal of Humanities and Social Science. 9(1):1928.

Goyal, S.K., Suhag, K.S., and Pandey, U.K. 2006. An Estimation of Technical Efficiency of Paddy Farmers in Haryana State of India. Indian Journal of Agricultural Economics. 61 (1):108122.

Hasnain, M.N., Elias, M.H. and Khairul, M.I. 2015. Technical Efficiency of Boro Rice Production in Meherpur District of Bangladesh: A Stochastic Frontier Approach. American Journal of Agricultural and Forestry. 3(2):31-37

Irawan, B. 2005. Konversi Lahan Sawah: Potensi, Dampak, Pola Pemanfaatannya dan Faktor Determinan. Forum Penelitian Agro Ekonomi. 23 (1):1-18.

Ishak, A. dan Afrizon. 2011. Persepsi dan Tingkat Adopsi Petani Padi Terhadap Penerapan System of Rice Intensification (SRI) di Desa Bukit Peninjauan I, Kecamatan Sukaraja, Kabupaten Seluma. Infomatika Pertanian. 20 (2):76-80.

Jondrow, J., Lovell, C.A., Materov, I.S., Schmidt, P. 1982. On Estimation of Technical Inefficiency in The Stochastic Frontier Production Function Model. Journal of Econometrics. 19 (1):233-238.

Nikhil, P.P.R and Azeez, P.A. 2011. Allocative Efficiency in Paddy Cultivation in The Command Area of Malampuzha River Valley Project, India. Global Research Journal of Agricultural and Biological Sciences. 4 (1):17-22.

Pirngadi. 2009. Peran Bahan Organik Dalam Peningkatan Produksi Padi Berkelanjutan Mendukung Ketahanan Pangan Nasional. Pengembangan Inovasi Pertanian. 2 (1):48-59.

Sato, S. 2007. SRI mampu tingkatkan produksi padi nasional. [diakses tanggal 13 Oktober 2015]. Tersedia pada laman: http:/ / www.merdeka.com/uang/srimampu-tingkatkan-produksi-padinasional-hqmffn6.html
Simanhuluk, B.W., Agus, P., Feli, A. 2011. Adopsi Petani Terhadap System of Rice Intensification (SRI) di Desa Bukit Peninjauan I Kecamatan Sukaraja Kabupaten Seluma. Jurnal Agribis. 4 (2):279-285.

Tadesse, B., Krishnamoorthy, S. 1997. Technical Efficiency in Paddy Farms of Tamil Nadu: An Analysis Based on Farm Size and Ecological Zone. Agricultural Economics. 16 (1997):185192.

Udayanganie, A.D.D., Prasada, D.V.P., Kodithuwakku, K.A.S.S., Weerahewa, J., and Little, D.C. 2006. Efficiency of The Agrochemical Input Usage in The Paddy Farming Systems in The Dry Zone of Sri Lanka. Prepared for The Annual Meeting of The Canadian Agricultural Economics Society; 2006 May 25-28; Montreal, Quebec.

Uphoff, N. 2002. Oppourtunities for Raising Yields by Changing Management Practices: The System of Rice Intensification in Madagascar. Agroecological Innovations. Earthscan Publications Ltd. London.

Wardana, P.I., Juliardi, Sumedi, dan Iwan, S. 2005. Kajian Perkembangan System of Rice Intensification (SRI) di Indonesia. Jakarta: Kerjasama Yayasan Padi Indonesia dengan Badan Litbang Pertanian. 
